\title{
Seeing the Superiority of Self-monitoring Learning Strategies over Teacher-monitoring Learning in Adult 'Reading Comprehension'
}

\author{
Asghar Bastami Bandpay \\ English Language Department, IAU, Lahijan Branch, Iran \\ Tel: 98-9113424077_E-mail: alibastami75@yahoo.com
}

Received: October. 26, 2012 Accepted: December 11, 2012 Published: February 1, 2013

doi:10.5296/jse.v3i1.2573 URL: http://dx.doi.org/10.5296/jse.v3i1.2573

\begin{abstract}
This study aims to see the superiority of SMLS on Learners' Receptive skill among the students of Payame-noor and Azad Universities in three different departments and the evaluation that teachers can apply to raise SML among adult learners. It is believed that since the publication of Malcolm Knowles' book in 1975, SML had been applied for adult education for ages. To administer this, SML of reading comprehension was introduced to learners in order to keep an eye on their own learning. To this end, metacognitive strategies rather than cognitive have been more highlighted. To answer, a proficiency test was administered to a total of 382 EFL learners, out of which 200 participants whose scores ranged from 65-80 out of 100 were chosen as the upper-intermediate level as an experimental and control group which were administered the same syllabus and assessment procedures. TOEFL reading test was the instrument of the study. Finally, the data was analyzed through SPSS, using Ttest. Results showed that a significant difference between mean score of TML and SML exist, and the superiority of SML became more highlighted when learners did better after treatment.
\end{abstract}

Keywords: SML, TML, Cognitive, Metacognitive Strategies, TOEFL reading test 


\section{Introduction}

Reading a text was always a big issue for students in general from different aspects of view especially understanding or comprehending what the text meant. Non-native English students namely, Iranian EFL learners are more concerned with getting the correct answer/s of Reading Comprehension questions than with more important process of how to get the answer since high-school. It is believed that using dictionary is somehow boring for them but the learners depend too much on the dictionary to look up every unknown word owing to being Non-native. In order to help learners overcome these problems, teachers should show the learners different ways or techniques, e.g., He or she can ask them to read each line and underline unknown words without looking up the meaning in dictionary; to use contextual clues to guess the general meaning of that not in isolation; to skip unnecessary unknown words; and break them up into root. That is, prefix and suffix.

When the teachers help learners develop awareness about their own thinking and learning processes, the teachers are helping learners think about the effectiveness of the strategies they use in reaching the goals they have set. Fundamentally, they are "thinking about thinking," a process known as metacognition. Generally speaking, use of a long-term metacognitive strategy of planning what is to be done, monitoring our progress, and evaluating the results is an effective way of helping learners take more control of their own thought and feeling processes (Block, 2004). The literature of metacognitive strategies in reading comprehension reveals that poor readers in general lack effective metacognitive strategies and have little awareness on how to approach to reading. They also have deficiencies in the use of metacognitive strategies to monitor for their understanding of texts. Conversely, successful L2 readers know how to use appropriate strategies to enhance text comprehension (e.g., Pitts, 1983). According to Block (2004), " metacognition [in this field] can be defined as a reader's awareness of (1) what he or she is thinking about while reading, (2) what thinking processes he or she initiates to overcome literacy challenges, and (3) how a reader selects specific thinking processes to make meaning before, during, and after reading".

As far as learning strategies are concerned, Knowles believed that there are two kinds of learners namely, Pro-active learners and Reactive learners who learn differently. Referring to the unanimity among researchers about this classification, Knowles (1975) claimed that people who have creativity and take the initiative in learning (pro-active learners) learn more things and learn better than do people who sit at the feet of teachers passively waiting to be taught (reactive learners). (Knowles 1975: 14)

The main characteristic of self-directed learning is the degree to which the learner maintains active control of the learning process (Long 2002). An emphasis on learner's self- monitoring and efficacy or productiveness means that the related teacher teach and involve students in specific strategies that offer the learners opportunities to make decisions and solve problems on their own without being told what to do at all times. It means the teacher provides the learners with strategies designed to help them process information effectively and to be self-confident, believing that they have the abilities to succeed. Simply speaking, when there is a will, there is 
a way. And perhaps most important, we help students become more reflective about their thinking and learning processes.

The practical view of this present study is to discover the superiority of self- monitoring on EFL learners' Receptive skills namely in this research reading comprehension proficiency, learners' achievements, the effective and positive role of teacher especially in this field, plus giving some useful tips relating to reading strategies in order to provoke and promote self-determination and independence. Hence, the obvious strategies that teacher can imply is inspiring and motivating the learners to set their own aims for personal development and instructional improvement as well as exploring short-cut to achieve these goals.

To have an accurate shoot relating to their goals, EFL learners can take advantages of learning a variety of problem solving strategies as well. To do this, the participants were taught and practiced preferably through metacognitive strategies, as mentioned above, in SML reading strategies Based on this objective, a research question was constructed.

\section{Research Question of the study}

The present study aims to answer the following research question:

Does SML have any superiority over TML and any effect on reading comprehension proficiency?

\section{The Hypotheses of this study}

The hypotheses of this present study are as follows:

H0. Self- monitoring strategies do not have any significant influence on EFL learners' reading comprehension proficiency over teacher- monitoring strategies.

H0. The superiority of SMS is not more than TMS in adult education.

Some key concepts concerning the subject are brought in the following to grasp the text efficiently.

\subsection{Definition of Terms}

\subsubsection{Self- monitoring learning}

A process in which individuals take the initiative, with or without the help of others.

\subsubsection{Transformational learning}

Critical reflection by the learner as central to the process.

\subsubsection{Emancipatory learning}

positioned more for social and political action than individual learning.

\section{Literature Review}

As the name rings a bell, the meticulous definition of Self- monitoring learning can imply independence, self-determination, autonomous learning, self-directed, self-assessment, learner 
strategies, self-help learning strategies, strategic investment, learner training, self-study, self-access learning. All these terminologies or key concepts that have emerged according to a pivot related to learner autonomy (which for our purposes can be taken as synonymous with self-directed learning) as a goal for learners, and learner training, or the teacher's encouragement of their efforts towards that goal.

Andragogy or adult education, which was concerned with adult learners, was first introduced by the father of the adult education, Malcolm Knowles. After that another model of learning appeared as self- monitoring learning when he was introducing this system of learning to North American adult educators. By emerging of Self- monitoring learning, the distinction between adult learning and children learning was highlighted.

Knowles (1975) himself contributed to the self-directed learning literature with his book "Self-Directed Learning: A Guide for Learners and Teachers, "published in 1975, describing self-directed learning as "a process in which individuals take the initiative, with or without the help of others", explaining the concept and outlining how to implement it through learning contracts. And it might be recalled that the first assumption underlying Knowles's view of andragogy is that learners become increasingly self-directed as they mature. The processes in self- monitoring learning include diagnosing one's own learning needs, setting personal goals, making decisions on resources and learning strategies and finally assessing the value of the outcomes (1968).

The second goal is the fostering of transformational learning (Brookfield, 1986, Mezirow, 1985). Transformational learning as presented by Mezirow posits critical reflection by the learner as central to the process. This critical reflection is an "understanding of the historical, cultural, and biographical reasons for one's needs, wants, and interests. . . . Such self-knowledge is a prerequisite for autonomy in self-directed learning". (Mezirow, 1985, p. 27)

The third goal for self- monitored learning is the promotion of emancipatory learning and social action. Just as andragogy has been criticized for ignoring the context of learning, so some writers would like to see self- monitored learning to be positioned more for social and political action than individual learning. Both Brookfield (1993) and Collins (1996) call for a more critical, political analysis of SML.

How one actually works through a self- monitored learning experience has generated a number of models of the process. The earliest models proposed by Tough (1971) and Knowles (1975) are the most linear, moving from diagnosing needs to identifying resources and instructional formats to evaluating outcomes. Models developed in the late 1980s and the 1990s are less linear and more interactive; in such models not only the learner but the context of the learning and the nature of the learning itself are taken into account. In Danis's (1992) model, for example, learning strategies, phases of the learning process, the content, the learner, and the environmental factors in the context must all be taken into account in mapping the process of SML. 
Victori and Lockhart (2000) believe that one of the premises of any self-directed program, we believe, should be that of enhancing students' metacognition to prepare them for approaching their own learning autonomy. Such a program should involve cyclic diagnosis of learners' beliefs about language learning, preferred styles, learning needs and objectives in order to endow the learners with criteria for choosing optimum strategies, resources and activities for their individualized program. Their purpose was to highlight the unifying role of metacognition in all levels of learner training.

What Merriam and Caffarella (1999) term "instructional" models of the process focus on what instructors can do in the formal classroom setting to foster self- monitoring and student control of learning. The best known of these is Grow's $(1991,1994)$ Staged Self- monitored Learning (SSML) model. Grow presents a matrix whereby learners can locate themselves in terms of their readiness for and comfort with being self- monitored, and instructors can match the learner's stage with appropriate instructional strategies. For example, whereas a dependent learner needs more introductory material and appreciates lecture, drill, and immediate correction, a self- monitored learner can engage in independent projects, student-directed discussions, and discovery learning.

In addition to goals and process, the literature can be categorized according to the learner and the extent to which self-directedness is a priori personal characteristic and associated with other variables such as educational level, creativity, learning style, and so on. Two scales of self-directedness, one measuring readiness (Guglielmino, 1997), and one measuring personal characteristics (Oddi, 1986), have been used in a number of studies. In addition to these empirical studies, the relationship between autonomy and self-directedness has been explored. Candy (1991, p. 309) writes that since a learner's autonomy is likely to "vary from situation to situation," educators should not assume that because a person has been self- monitored in one situation, "he or she will be able to succeed in a new area: Orientation, support and guidance may all be required in the first stages of a learning project." Furthermore, Matuszowicz (1996) provides one example of this in his work focused on developing self- monitoring in homeless adults. For perhaps the first time in their lives, this group recognized themselves and others as learning resources and learned through the practice of interpersonal behaviors and skills such as giving and receiving feedback. Similarly, in British open learning centers, O'Mahony and Moss (1996) found that adult basic education students "identified a common bond and developed a collective self- monitor " (p. 30) through work on a student committee; they also enhanced their sense of individual self-direction. A study of empowerment in community groups (Singh 1993) suggests that group learning processes can empower individuals to move from low to high self-directedness. In addition, the enhancement of individual SML abilities tended to help groups become more empowering.

Guthrie, et al. (1996) noted that the self- monitored learners in a Concept-Oriented Reading Instruction (CORI) program demonstrated the ability to search for information in multiple texts, employ different strategies to achieve goals, and to represent ideas in different forms (drawing and writing). Morrow, et al. (1993) observe that with proper planning and implementation, self- monitored learning can encourage students to develop their own rules and leadership patterns. 
In one school of thought, SML is based on the autonomous, independent individual who chooses to undertake learning for personal growth (Merriam and Caffarella 1999). Braman's (1998) review of literature suggests that the SML construct has been primarily based on individualistic attitudes and values, in keeping with the viewpoint that lifelong learning has primarily instrumental objectives related to individual responsibility and work force development. So, the goals of an individual and his/her cultural group may conflict, thus hindering the opportunity for self- monitor.

However, another school of thought stresses the social construction of knowledge and the social context of learning. One of Brookfield's criticisms of SML research (cited in Long 1994) was that it ignored social context by focusing on the individual, isolated learner, although Long refutes Brookfield's criticism in an analysis of more than 500 studies, as much as $90 \%$ of which were concerned with SML in social settings. Maehl (2000) asks, "Is self-directed learning possible if knowledge is socially or culturally constructed" (p. 51). Rowland and Volet (1996) also call for more awareness of socio-cultural perspectives. They suggest that a more postmodern view of the self in self- monitored learning challenges the notion of universal individualism and that, from this perspective, adult learning has significance "for a learner's community as well as for the individual" (p. 100). Moreover, O'Donnell (1999) goes the furthest in emphasizing the collective over individual dimension when he presents a rationale for what he calls "selves- monitored learning" (p. 251).

In this paper we will argue Braman's (1998) view that he believes goals of an individual and his/her cultural group may hinder the opportunity for self- monitor. we will present data that support Rowland and Volet's (1996) view that adult learning has significance "for a learner's community as well as for the individual" by making learners practice in groups and examine individually.

\subsection{Self- Monitored Learners}

Self- monitored learning, which has its roots in adult education, is an approach that has been tried with learners in elementary and secondary schools. There may be slight variations in how different educators define SML, but a survey of the literature on the subject identifies several tenets that are central to the concept.

As the term suggests, SML views learners as responsible owners and managers of their own learning process. SML integrates self-management (management of the context, including the social setting, resources, and actions) with self-monitoring (the process whereby the learners monitor, evaluate and regulate their cognitive learning strategies) (Bolhuis, 1996; Garrison, 1997).

SML recognizes the significant role of motivation and volition in initiating and maintaining learners' efforts. Motivation drives the decision to participate, and volition sustains the will to see a task through to the end so that goals are achieved (Corno, 1992; Garrison, 1997).

In SML, control gradually shifts from teachers to learners. Learners exercise a great deal of independence in setting learning goals and deciding what is worthwhile learning as well as how 
to approach the learning task within a given framework (Long,1994; Morrow, Sharkey, \& Firestone, 1993).

Teachers scaffold learning by making learning 'visible.' They model learning strategies and work with students so that they develop the ability to use them on their own (Bolhuis, 1996; Corno, 1992; Leal, 1993). SML is, ironically, highly collaborative. Learners collaborate with teachers and peers (Guthrie, Alao \& Rinehart; 1996; Temple \& Rodero, 1995). SML develops domain-specific knowledge as well as the ability to transfer conceptual knowledge to new situations. It seeks to bridge the gap between school knowledge and real-world problems by considering how people learn in real life (Bolhuis, 1996; Temple \& Rodero, 1995). Students learn to identify and value their own experiences in life. They learn to value personal experiences of others. They develop critical thinking, individual initiative, and a sense of self-worth and self-confidence. Through SML, it is possible to learn how to learn, to learn how to see, to learn how to be, in always that make one more self- monitoring many areas of life. It is a situational attribute an impermanent state of being dependent on the learner's competence, commitment, and confidence at a given moment in time (Pratt 1988, p.162).

The benefits of SML are best described in terms of the type of learners it develops. The literature on SML asserts that self- monitored learners demonstrate a greater awareness of their responsibility in making learning meaningful and monitoring themselves (Garrison, 1997). They are curious and willing to try new things (Long, 1994), view problems as challenges, desire change, and enjoy learning (Taylor, 1995). Taylor also found them to be motivated and persistent, independent, self-disciplined, self-confident and goal-oriented. Self- monitored learning allows learners to be more effective learners and social beings.

Depending on the philosophical orientation of the writer, the goals of self- monitored leaning vary. Those grounded in a humanistic philosophy posit that self- monitored learning should have as its goal the development of the learner's capacity to be self- monitored. Knowles and Tough (1967) wrote from this perspective as do Brockett and Hiemstra (1991). In their Personal Responsibility Orientation (PRO) model of self- monitored learning, human nature that is "basically good ... accepting responsibility for one's own learning" and being proactive drive their model.

\subsection{The Role of Teacher in Self- monitored Learning}

The most important object of educational process is to produce self- monitored, life-long learners. Many current educational practices in public schools and universities; however, do more to perpetuate dependency than to create self- monitor. Moreover, there is more than one way to teach well. With some exceptions, good teaching is situational -it varies in response to learners. The teacher begins to provide some key characteristics of a learner who can take responsibility for learning: an ability to define one's own objectives; awareness of how to use language materials effectively; careful organization of time for learning, and active development of learning strategies.

Knowles visualizes the teacher role as that of facilitator of learning rather than teacher, procedural guide rather than content transmitter. One of the most important tasks of the teacher 
is to raise student awareness of their roles in learning. Taylor (1995) suggests engaging students in discussion on topics from the Self- monitored Learning Readiness Scale. Examples of topics: I know that I want to learn and that I am a learner, so if I want to learn something, I can, and I like to learn and to solve problems because I know that thinking 'hard' can be fun. The exercise of evaluating oneself on such topics was found to have positively influenced learner awareness. Long (1994), who works with readers, suggests generating similar discussion through the use of questions designed to help learners become aware of what good readers do and how to become one. Among the examples he provides are: Did you read better today than yesterday? Could you keep the ideas in your book straight in your mind? Were there words you did not know? How did you figure them out?

Another fundamental aspect of the SML approach is Learner participation in decision-making. Taylor advocates involving students in decisions concerning what is to be learned, when and how it should be learned, and how it should be evaluated. In addition, every proponent of SML emphasizes the importance of allowing learners to pursue their own interests so that learning becomes more meaningful. Morrow, et al. (1993) report that when writers are allowed to choose their own topics, they write more often and they write longer pieces. Students do not have to be given total freedom, however. Teachers could, for instance, establish a thematic framework within which students are given choices (Guthrie, et al., 1996; Temple \& Rodero, 1995). Teachers in this approach lead students to take responsibility of their own learning, encourage them to cooperate and consult with each other.

Long (1994) and Bolhuis (1996) stress that teachers who want to encourage SML must free themselves from a preoccupation with tracking and correcting errors, a practice that is ego-threatening (Guthrie, et al. 1996). Long and Bolhuis advocate greater tolerance of uncertainty and encourage risk-taking, and capitalizing on learners' strong points instead of focusing on weaknesses, as it is more beneficial for learners to achieve a few objectives of importance to them than it is to fulfill all the objectives that are important to the teacher. Leal (1993) advocates allowing learners to explore ideas through peer discussions - even without fully intact answers - a process that can yield new and valuable insights. Corno (1992) suggests allowing learners to pursue personal interests without the threat of formal evaluation. Even if they make mistakes while doing so, the activities will sustain their interest, transcend frustration, and eventually break barriers to achievement. According to Leal, Uninterrupted Sustained Silent Reading (USSR) may be one way of accomplishing this objective in the reading classroom.

To establish the habit of self-monitoring, teachers need to encourage learners to reflect on what they did and to revise attempted work (Corno, 1992). Keeping journals is one way of maintaining a record of the learning process. Teachers also need to modell learning strategies such as predicting, questioning, clarifying, and summarizing, so that students will develop the ability to use these strategies on their own. Teachers also need to allow individual learners to approach a task in different ways using different strategies (Many, Fyfe, Lewis \& Mitchell 1996). Teacher should help students begin to recognize their different personality types, life-goals, and styles of learning; set high standards and motivate students to achieve them. 
Since SML stresses meaningful learning, Temple and Rodero (1995) advocate a situated learning approach, in which teachers bring real-life problems into the classroom for learners to work on. They advise against 'sugar-coating' work with fun, the rationale being that if the tasks are meaningful, learners will work on them willingly. Learners should also be allowed to collaborate with the teacher in determining deadlines and other regulations. For the language teacher, the issue is whether it is possible to help learners acquire and develop strategies of either kind which will enhance their ability to learn inside and outside the classroom.

Researchers have found that as children grow, they have an increasing desire for autonomy. SML may be one way of harnessing that natural desire to help achieve a meaningful learning experience that will last through adulthood. Moreover, teaching reading strategies to self-monitor meaning can help students to become true readers.

\subsection{To Promote Self- monitored Learning through Reading Strategies}

Reading comprehension strategies are seen as comprehension processes that enable readers to construct meaning from the printed page most effectively. In other words, those strategies show how readers tackle a reading task, how they interpret their reading and what they do when they do not comprehend. Good readers draw on prior knowledge and experience to help them understand what they are reading and are thus able to use that knowledge to make connections. Struggling readers often move directly through a text without stopping to consider whether the text makes sense based on their own background knowledge, or whether their knowledge can be used to help them understand confusing or challenging materials. By teaching students how to connect to text they are able to better understand what they are reading (Harvey \& Goudvis, 2000). Accessing prior knowledge and experiences is a good starting place when teaching strategies because every student has experiences, knowledge, opinions, and emotions that they can draw upon.

Tovani (2000) offers reasons why connecting to text helps readers:

- It helps readers understand how characters feel and the motivation behind their actions.

- It helps readers have a clearer picture in their head as they read thus making the reader more engaged.

- It keeps the reader from becoming bored while reading.

- It sets a purpose for reading and keeps the reader focused.

- Readers can see how other readers connected to the reading.

- It forces readers to become actively involved.

- It helps readers remember what they have read and ask questions about the text

Reciprocal Teaching is an instructional strategy for teaching strategic reading developed by Annemarie S. Palincsar that takes place in the form of a dialogue between teachers and students. In this dialogue the teacher and students take turns assuming the role of teacher in leading the dialogue about a passage of text. Four strategies are used by the group members in the dialogue 


\section{Macrothink}

Journal of Studies in Education

ISSN $2162-6952$

2013, Vol. 3, No. 1

to use reading comprehension strategies independently, including text prediction, summarization, question generation, and clarification of unknown or uncllear content. At the start the adult teacher is principally responsible for initiating and sustaining the dialogue through modeling and thinking out loud. As students acquire more practice with the dialogue in small groups, the teacher consciously imparts responsibility for the dialogue to the students, while becoming a coach to provide evaluative information and to prompt for more and higher levels of participation. This shift from an instructor-centered approach to a student-centered approach is a central component of the reciprocal teaching process and encourages self-regulation on the part of the students (Palincsar and Brown, 1986). (For more information see: Palincsar and Brown 1984; Peter E. Doolittle, et al 2006; Oczkus, 2003).

There are a lot of other recent researches and strategies to promote learner autonomy but due to limitations of research it is impossible to mention and elaborate all of them during this paper.

\section{Method}

\subsection{Participants of the study}

In order to provide the required empirical data for this present study, a general proficiency test was administered to a total of 382 female and male university students of Payame-noor and Azad Universities in Gilan in three different departments (Humanities, Basic Sciences and Technical Engineering) as EFL learners with the same background knowledge for homogeneity, out of which 200 participants whose scores ranged from 65-80 out of 100 were chosen as the main participants namely, as the upper-intermediate level as an experimental and control group. The control group trained in TML and the experimental group trained and practiced SML reading strategies in a 10-week course of English reading texts. The class met twice per week for a total of 10 weeks, with each class meeting lasting approximately 90 minutes every session 45 minutes using SML approach with strategy training and practice. The average of their ages is 20 to 25 .

Table 3.1. Distribution of Participants According to Gender

\begin{tabular}{llcc}
\hline & & Number & Percent \\
\hline Valid & male & 100 & $50 \%$ \\
& female & 100 & $50 \%$ \\
& total & 200 & $100 \%$ \\
\hline
\end{tabular}

\subsection{Material of the study}

In this present study, the researcher divided the procedure into two phases. In the first phase, the researcher administered a proficiency test to tap and measure the participants' general proficiency in English and to insure that they all belonged to the same population. The proficiency test 'TOEFL', the first instrument utilized in this study, consisting of three parts was administered. The first and second parts contained 70 items on Vocabulary, Reading and 


\section{Macrothink Institute ${ }^{\mathrm{TM}}$}

Writing Test and the third part consisted of 30 items on Listening Test done by the researcher as an 'upper-intermediate level' for the present study. As the respective studlents both in control (TML) and experimental (SML) group were assessed individually in a TOEFL reading comprehension test before, to homogenize, and Then, in the second phase, in order to check the participants' performance on the advantages of each TML and SML, the researcher used another test consisted of three parts as shown in the following table, that is, a-20-session practice administered to see the superiority of each TML and SML. Materials are similar both in format of questions and their level. Learners had 30 minutes to answer the questions. The test consists of 3 parts with a total of 13 questions:

- 4 items in part A that learners were supposed to choose the most suitable heading for each section/paragraph from the list of headings.

- 5 items in part B to answer multiple-choice questions

- 4 items in part C to identify True/False/Not Given statements to reflect the opinions are implied or stated by the text.

Table 3.2. Distribution of items According to proficiency test (TOEFL)

\begin{tabular}{lll}
\hline \multicolumn{1}{c}{ section } & Items \\
\hline Part $1 \& 2$ & Vocabulary, Reading comprehension and Writing Test & $\mathbf{7 0}$ \\
Part 3 & Listening Test & $\mathbf{3 0}$ \\
Total & & $\mathbf{1 0 0}$ \\
& & \\
\hline
\end{tabular}

Table 3.3. Distribution of items According to a 20-session practice

\begin{tabular}{lll}
\hline & \multicolumn{1}{c}{ section } & Items \\
\hline Part 1 & Best heading & 4 \\
Part 2 & Multiple choice & 5 \\
Part 3 & True / false & 4 \\
& & 13 \\
Total & & 13 \\
\hline
\end{tabular}

\subsection{Procedure of the study}

In this present study, the researcher designed and applied two ways of administration. For the first group, control group (TML) students experienced summary writing and rehearsing strategies in which they are only passive recipients of the meaning their teacher construct from the printed passage and never try to use the knowledge of their own to understand the subject 


\section{Ml Macrothink}

Journal of Studies in Education

ISSN 2162-6952

2013, Vol. 3, No. 1

better and the second group, experimental group (SML) learners are trained and practiced in pre, during and post reading strategies. The researcher develop an instruction curriculum to practice some control of the learners' own learning that include having them to predict text content using the title and picture illustrations or information, using contextual clues and key words to aid comprehension, paraphrasing, vocabulary drills and students should write their own story endings using the list of predicted conclusions within small group components focusing on helping learners develop general comprehension strategies that could be used to access meaning in a broad array of texts, regardless of the texts' vocabulary and/or grammatical features as well as asking some problem solving questions and have a student discussions or projects around the topic to enable them make decisions on their own and also be able to relate the subject to their own experiences. The teacher first models these metacognitive strategies and then asks the students to regulate their own learning and self-evaluate them. Learners at this stage are both able and willing to take responsibility for their learning, direction, and productivity. They practice skills in time management, project management, goal setting, self-evaluation, peer critic, information gathering and use of educational resources.

After that, learners apply higher-order thinking strategies which help them construct meaning from what they read and help them monitor their progress toward their goals. As learners gain practice and confidence in using these strategies -within small groups and then as individual readers, the teacher assesses individual learners' abilities to comprehend a text through a specifically English reading proficiency test of TOEFL.

The learners both in control and experimental group completed a post-test that closely paralleled the pre-test. After that, learners in experimental group are interviewed after treatment and it reveals that all of the learners have positive attitudes toward SML owing to grasping what they need, relying more on their talent and abilities and more importantly, feeling that they can really benefit from this strategy and this all is because SML gives them self-confidence, autonomous, self-management and so forth.

\subsection{Statistical procedure of this study}

The statistical procedure is based on computer-assisted programs spss. The Data analysis is a process of gathering, modeling, and transforming data with the goal of highlighting useful information, suggesting conclusions, and supporting decision making. Having administered the instruments for this research, the responses were collected and interpreted. The data gathered by the experiment of the study was analyzed through T-Test 'Independent Samples Ttest, using the spss analysis method that is discussed below.

\subsection{The design of the study}

The design of the study is based on pre-test and post-test design and the schematic representation is as follows:

$\begin{array}{lll}\text { Group 1 } & \text { T1 } & \text { T2 } \\ \text { Group 2 } & \text { T1 } & \text { T2 }\end{array}$




\section{Result}

The paired samples t-test has been displayed in Table1. :

Table1 (a). Group Statistics of the Study

\begin{tabular}{|l|l|l|l|l|l|}
\hline \multicolumn{6}{|l|}{ Group Statistics } \\
\hline & Group & $\mathrm{N}$ & Mean & Std. Deviation & Std. Error Mean \\
\hline \multirow{2}{*}{ Reading } & TML & 100 & 14.6848 & 1.33483 & .19681 \\
\cline { 2 - 7 } & SML & 100 & 17.9565 & 1.38575 & .20432 \\
\hline
\end{tabular}

Table1 (b). Independent Samples t-test of the Study

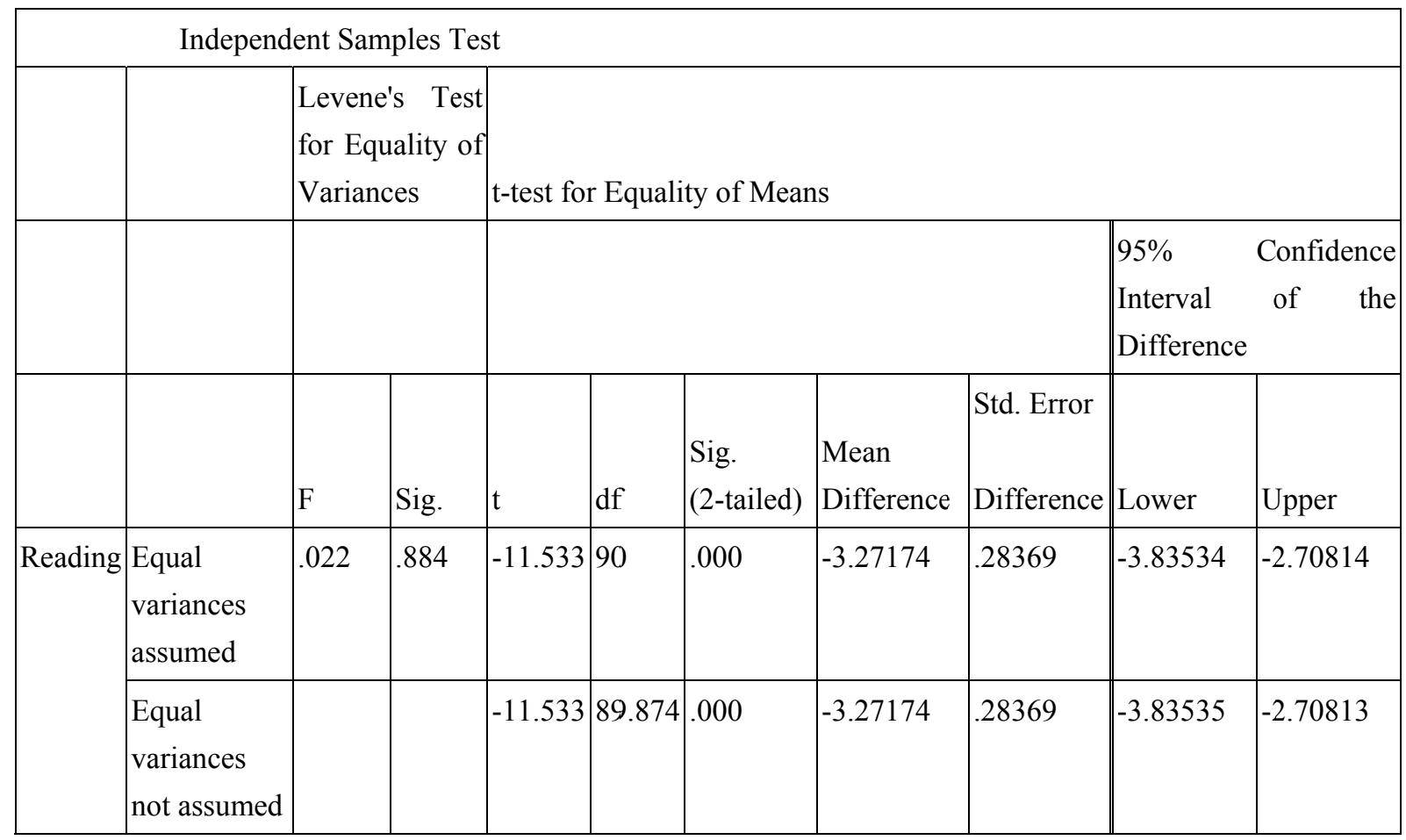

In Table1 (a), the mean score for the TML group and for the SML group is about 14.68 and 17.95 respectively. This shows that mean score of SML group is more than that of TML which proves better performance of the self-monitored learners of the study over teacher- monitored learners, but these differences in these two groups are not significantly noticeable and meaningful to result in complete superiority of SML over TML. So it needs to compare the means through the Independent Samples t-test.

In Table 1 (b), the Independent Samples T-Test reveals a statistically reliable difference between the mean score of TML that has Mean=14.68, $\mathrm{SD}=1.33$ and SML has Mean=17.95, $\mathrm{SD}=1.38, \mathrm{t}(90)=11.53, \mathrm{P}=0.00, \alpha=0.05$. 
$\mathrm{P}<0.05 \quad \rightarrow \quad$ The null hypothesis is rejected.

\section{Discussion and Conclusion}

As far as this study is concerned the null hypothesis is rejected relating to self- monitored strategies have no significant influence on Iranian EFL learner's reading comprehension proficiency. And at the end of the course the strategic learners that were equipped with SML strategies were able to identify their own learning needs, setting personal goals, making decisions and generally to take the responsibility of their own learning not only in the educational context but also be able to succeed in any new areas and contexts and their learning is much more purposeful and planned than TML groups that it promotes collaborative learning among students.

This study aims to see the superiority of self-monitored on learners' proficiency of reading comprehension, students' accomplishments, teachers' role in this area and suggesting some tips about learning strategies so that EFL learners can read different texts of not only their textbooks but also other sources like magazines, newspapers, etc to comprehend them effectively and efficiently without relying, to some extent, on dictionary and referring to it a lot. Moreover, the long-term objective of the SML is a life-long learning particularly in adult education. A touchstone of effective learning is that students are in charge of their own learning; essentially, they direct their own learning processes. SML enable learners to be efficient, active, motivated learners. They no longer get bored with this task. They set their own personal goals and pursue personal interests. But the problems arise when the teaching style is not matched to the learner's degree of self-monitored and the students are not directed properly in the first stages of learning. On the other hand, it needs learners to collaborate with teacher. The data analyzed through t-test indicates a significant difference between mean score of the two groups that confirms the great outperformance of students after treatment.

\section{Implications and Further Research}

In this study there are implications for:

English teachers to pay much more attention to learners' reading comprehension with regard to the value of the strategy training in the language classes to enable students to learn more efficiently and become autonomous learners. It may allow teachers to obtain an awareness of the likely problems to be incurred by the learners' lack of familiarity with such strategies. Furthermore, teachers can teach in more than one style.

Students to know how to carry out this task efficiently and independently. It can also assist learners to invent strategies of their own and use metacognitive strategies to monitor for their understanding of texts

This could be attributed to EFL/ESL learners both in local schools and English schools. SML generally meets with active cooperation from students.

The main pedagogic aim is that, upon the implementation of a new methodology to improve learners' reading comprehension, which combines self-monitored strategies with 
metacognition focused tasks; students are expected to develop a highly acceptable comprehension competence to become self-regulate learners.

SML has some other strategies not only in reading skill but also in other skills of learning English and any other languages and is applicable to other fields of study, so teachers can use any of these strategies interchangeably based on learner objectives. We suggest that the door is now open and there is a scope for the development of future research in this area with regard to other skills that have significant influence on the proficiency of EFL/ESL learners. Self-directed learning is the method used when a learner, rather than an institution, controls both the learning objectives and the means of learning. It is a continuous process, often informal, and an important factor in lifelong learning. Many adults engage in self- monitored learning to improve their work performance. Others carry on self- monitored learning in recreational arts and hobbies, matters of health, family and community, or simply to increase their intellectual resources. Consequently, the scope of this research could be enlarged to investigate the other fields of education and even life.

\section{The impressions of respective participants to the applied SML strategies}

- The strategies you applied made me conscious and active. I used to read a text word for word until then, being afraid to misunderstand the contents. Now I'm trying to skip as many words as possible even when I am going to read about something not familiar, and I am going to deal with the text I have already had quite a few knowledge.

- There are many positive aspects of using predictions. Firstly, we immediately think about the topics help us to understand contents of articles or some experiences of my own. Secondly, we can improve our reading speed by predicting the following contents.

Thirdly, we can associate our knowledge concerning the topics and it can help us to make our learning much easier.

- Finding key words in any text were an interesting technique. I think relying on key words is more helpful than relying on the structure in reading a text.

- This time I really enjoy my reading. I could not imagine that I could understand a text without knowing the meaning of new words using contextual clues.

- I no longer get bored with this task.

- Now I actively involved in the topic I am reading about and it's really challenging to discuss about reading text especially when some of my classmates have opposite ideas or when you ask a question and make us choose between these two questions.

- I can regulate my own reading strategies and I am aware of my own responsibility in learning.

-When you ask us some questions concerning the topic we really engaged in the text and I can remind what I learnt before.

- Now I know how to learn efficiently and actively thinking about the topic is really fun. 


\section{References}

Block, C. (2004). Teaching Comprehension: The Comprehension Process Approach. Pearson Education, Inc. Texas Christian University.

Bolhuis, S. (1996). Towards Active and Selfdirected Learning. Preparing for Lifelong Learning, with Reference to Dutch Secondary Education. Paper presented at the Annual Meeting of the American Educational Research Association (New York, NY, April 8-12, 1996).

Braman, O. R. (1998). The Cultural Dimension of Individualism and Collectivismas a Factor in Adult Self-Directed Learning Readiness. Ph.D. dissertation, University of Southern Mississippi.

Brockett, R. B., \& Hiemstra, R. (1991). Self-Direction in Adult Learning: Perspectives on Theory Research, and Practice. London and New York: Routledge.

Brookfield Stephen D. (1993). Self-Directed Learning. USA: Springer Netherlands.

Brookfield, S. (1986). Understanding and Facilitating Adult Learning. San Francisco: Jossey-Bass.

Candy, P. C. (1991). Self-Direction for Lifelong Learning. San Francisco: Jossey-Bass.

Collins, M.(1996). On Contemporary Practice and Research: Self-Directed Learning to Critical Theory. In R. Edwards, A. Hanson, and P. Raggatt (eds.), Boundaries of Adult Learning: Adult Learners, Education and Training. New York: Routledge.

Corno, L. (1992). Encouraging Students to Take Responsibility for Learning and Performance. Elementary School Journal; 93(1), 69-83. http://dx.doi.org/10.1086/461713

Danis, C. (1992). A Unifying Framework for Data-Based Research into Adult SelfApplication and Research. Norman: Oklahoma Research Center for Continuing Professional and Higher Education, University of Oklahoma.

Doolittle, Peter E. (2006). Reciprocal Teaching for Reading comprehension in Higher education: a Strategy for Fostering the Deeper Understanding of Texts. International Journal of Teaching \& Learning in Higher Education.

Garrison, D.R. (1997). Self-directed learning: Toward a comprehensive model. In Adult Education Quarterly, 48(1), 18, 16. http://dx.doi.org/10.1177/074171369704800103

Grow, G. (1991). Teaching Learners to Be Self-Directed: A Stage Approach. Adult Education Quarterly, 41(3), 125-149. http://dx.doi.org/10.1177/00018481910410030101

Grow, G. (1994). In Defense of the Staged Self-Directed Learning Model. Adult Education Quarterly, 44(2), 109-114. http://dx.doi.org/10.1177/074171369404400206

Guglielmino, L. M. (1997). Reliability and Validity of the Self-Directed Learning Readiness Scale and the Learning Preference Assessment (LPA). In H. B. Long and others (eds.), Expanding Horizons in Self-Directed Learning. Norman: Public Managers Center, University 
of Oklahoma.

Guthrie, J.T, and et al. (1996). Growth of Literacy Engagement: Changes in Motivations and Strategies during Concept-Oriented Reading Instruction. Reading Research Quarterly; v31 n3 p306-32 Jul-Sep 1996. [EJ 530 522]

Harvey, S. \& Goudvis, A. (2000). Strategies that work: Teaching comprehension to enhance understanding. Portland, ME: Stenhouse.

Knowles, M. S. (1968). Andragogy, Not Pedagogy. Adult Leadership, 16(10), 350-352,386.

Knowles, M. S. (1975). Self-Directed Learning. New York: Association Press.

Leal, D. J. (1993). The Power of Literary Peer-Group Discussions: How Children Collaboratively Negotiate Meaning. Reading Teacher; 47(2), 114-20.

Long, H. B. (1994). Challenging Some Myths about Self-Directed Learning. In New Ideas about Self-Directed Learning, by H. B. Long et al., pp. 1-14. Norman: University of Oklahoma.

Long H. B. (2002). Skills for Self-Directed Learning.

Maehl, W. H. (2000). Lifelong Learning at Its Best. San Francisco: Jossey-Bass.

Many, J.E., Fyfe, R., Lewis, G., \& Mitchell, E. (1996). Traversing the Topical Landscape: Exploring Students' Self-Directed Reading-Writing-Research Processes. Reading Research Quarterly; 31(1), 12-35.

Matuszowicz, P. F. (1996). Self-Directed Learning Readiness and Homelessness. (ED 404-472)

Merriam, S. B., \& Caffarella, R. S. (1999). Learning in Adulthood (2nd ed.). San Francisco: Jossey-Bass

Mezirow, J. (1985). A Critical Theory of Self-Directed Learning. In S. Brookfield (ed.), Self-Directed Learning: From Theory to Practice. New Directions for Education, no. 25. San Francisco: Jossey-Bass. Continuing

Morrow, L.M., \& Others (1993). Promoting Independent Reading and Writing through Self-Directed Literacy Activities in a Collaborative Setting.

O'Donnell, D. (1999). Habermas, Critical Theory and Selves-DirectedLearning. Journal of European Industrial Training 23(4-5), 251-261. http://dx.doi.org/10.1108/03090599910272121

O'Mahony, C., \& Moss, W. (1996). Self-Directed Learning: Liberating or Oppressive?: Developing Autonomy in Open Learning. In Lifelong Literacies. Papers from the 1996 Conference, Manchester, England, edited by S. Fitzpatrick and J. Mace, pp.28-33. Manchester, England: Gatehouse Books. (ED 411 448)

Oczkus, L. (2003). Reciprocal teaching at work. Newark, DE: International Reading 
Association.

Palincsar, \& Brown. (1984). Reciprocal Teaching of Comprehension- Fostering and Comprehension Monitoring Activities. Cognition and Instruction. Lawrence Erlbaum Associates, Inc. I (2) 117- 175.

Palincsar, A., \& Brown, A. (1986). Interactive teaching to promote independent learning from text. The Reading Teacher, 39, 771-777.

Pitts, M. M. (1983). Comprehension monitoring: definition and practice. Journal of Reading, 26, 516-23.

Pratt,D.D. (1988). Andragogy as a relational construct. Adult Education quarterly, 38,160-181. http://dx.doi.org/10.1177/0001848188038003004

Rowland, F., \& Volet, S. (1996). Self-Direction in Community Learning:A Case Study. Australian Journal of Adult and Community Education, 36(2), 89-102. (EJ 535 209)

Singh, P. B. (1993). The Relationship between Group Empowerment and Self-Directed Learning in Selected Small Groups in Michigan. Ph.D. dissertation, Michigan State University.

Taylor, B. (1995). Self-Directed Learning: Revisiting an Idea Most Appropriate for Middle School Students. Paper presented at the Combined Meeting of the Great Lakes and Southeast International Reading Association, Nashville, TN, Nov. 1999, 11-12.

Temple, C., \& Rodero, M.L. (1995). Active Learning in a Democratic Classroom: The "Pedagogical Invariants" of Celestin Freinet (Reading around the World). Reading Teacher, 49(2),164-67.

Tovani, C. (2000). I read it, but I don't get it: Comprehension strategies for adolescent readers. Portland, ME: Stenhouse.

Tough, A. (1967). Learning Without a Teacher. Educational Research Series, 3. Toronto: Ontario Institute for Studies in Education.

Tough, A. (1971). Major Learning Efforts: Recent Research and Future Directions. Adult Education, 28, 250-263. http://dx.doi.org/10.1177/074171367802800403

Victori Mia, \& Walter Lockhart. (2000). Enhancing metacognition in self-directed language learning. International Journal of Educational Research, 23(2). 


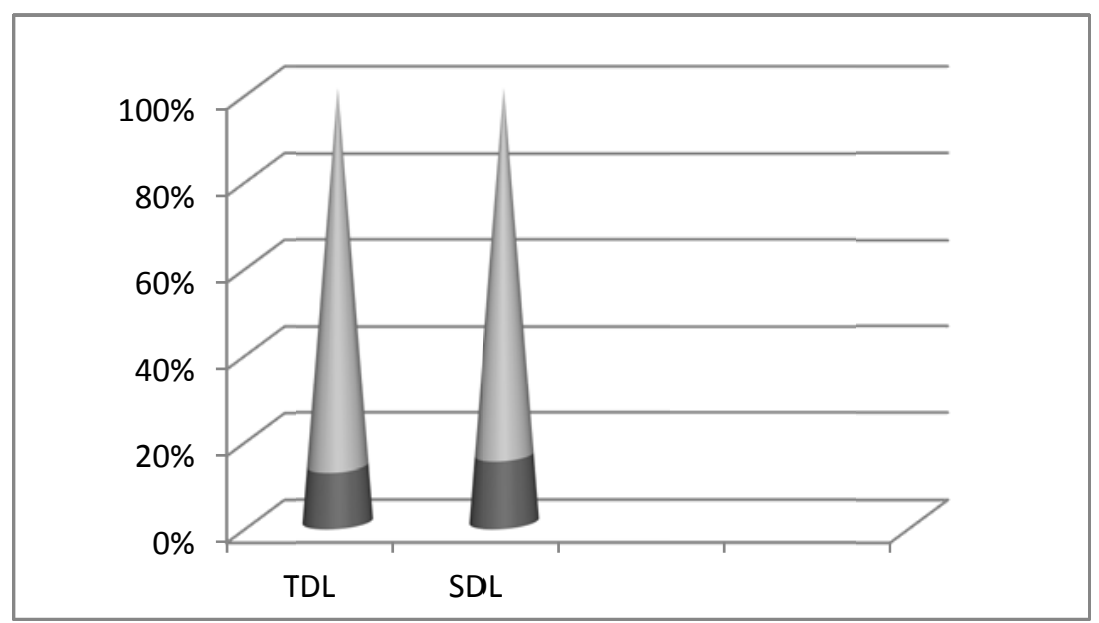

Figure 1. Mean Score TML-SML Diagram of the Study

Figure1, also, points that there is a significant difference between the mean score of TML and SML, and after treatment students in experimental group performed better that proves superiority of SML over TML strategies. 